\title{
Short rotation willow on the prairie potholes' degraded marginal riparian lands: a potential land-use practice to manage soil salinity
}

\author{
Shayeb Shahariar ${ }^{1}$, Raju Soolanayakanahally ${ }^{2}$, and Angela Bedard-Haughn ${ }^{1}$ \\ ${ }^{1}$ University of Saskatchewan \\ ${ }^{2}$ Indian Head Research Farm
}

May 2, 2021

\begin{abstract}
Land-use practice shift in the wetland riparian zone can influence groundwater table (GWT) fluctuations and salts dynamics, potentially leading to soil salinization. The risk of soil salinization linked with high water tables could better manage using high growing capacity and deep-rooted phreatophytic vegetation via 'biodrainage' approach. We evaluated the impacts of short rotation willow (SRW) plantation on soil and groundwater salinity linked to shallow GWT fluctuations and compared with adjacent annual crop (AC) and pasture (PA) in a field experiment. Groundwater salinity (ECgw) along with depth to GWT and soil salinity (ECsoil at 0-60 cm depth) were measured along transects within each land-use practice in two prairie pothole region $(\mathrm{PPR})$ wetland sites $(\mathrm{A}$ and $\mathrm{B})$. The variations in ECgw were significant $(\mathrm{p}<0.05)$ across land-uses; however, inconsistent between sites. The positive correlation with ECgw, ECsoil, and total dissolved salts (TDS) indicated higher salinity and salt accumulation with increased depth to GWT in both sites. The ECsoil varied significantly ( $p<0.05)$ among land-use practices; however, no consistent land-use patterns were observed between sites. Throughout the experimentation, site B consistently exhibited higher ECsoil (two-fold) than site A. Decreasing inclinations were observed in ECsoil with increasing SRW biomass at both depths (i.e., 0-30 and 30-60 cm) and vice versa. This study refines our knowledge of SRW linked potential hydrological alteration and its implication on salinity, which provides critical context for degraded marginal riparian wetland soil management in the PPR.
\end{abstract}

\section{Hosted file}

Manuscript_SRW on degraded marginal lands_with table.pdf available at https://authorea.com/ users/411364/articles/520429-short-rotation-willow-on-the-prairie-potholes-degradedmarginal-riparian-lands-a-potential-land-use-practice-to-manage-soil-salinity

\section{Hosted file}

Figures.pdf available at https://authorea.com/users/411364/articles/520429-short-rotationwillow-on-the-prairie-potholes-degraded-marginal-riparian-lands-a-potential-land-usepractice-to-manage-soil-salinity 